\title{
Presence and mobility of arsenic in estuarine wetland soils of the Scheldt estuary (Belgium)
}

\author{
G. Du Laing, ${ }^{* a}$ S. K. Chapagain, ${ }^{b}$ M. Dewispelaere, ${ }^{a}$ E. Meers, ${ }^{a}$ F. Kazama, ${ }^{b}$ F. M. G. Tack, ${ }^{a}$ J. Rinklebe $^{c}$ \\ and M. G. Verloo ${ }^{a}$
}

\author{
Received 10th September 2008, Accepted 9th January 2009 \\ First published as an Advance Article on the web 25th February 2009 \\ DOI: $10.1039 / b 815875 d$
}

\begin{abstract}
We aimed to assess the presence and availability of arsenic (As) in intertidal marshes of the Scheldt estuary. Arsenic content was determined in soils sampled at 4 sampling depths in 11 marshes, together with other physicochemical characteristics. Subsequently, a greenhouse experiment was set up in which pore water arsenic (As) concentrations were measured 4 times in a 298-day period in 4 marsh soils at different sampling depths $(10,30,60$ and $90 \mathrm{~cm})$ upon adjusting the water table level to 0,40 and $80 \mathrm{~cm}$ below the surface of these soils. The As content in the soil varied significantly with sampling depth and location. Clay and organic matter seem to promote As accumulation in the upper soil layer $(0-20 \mathrm{~cm}$ below the surface), whereas sulfide precipitation plays a significant role at higher sampling depths (20$100 \mathrm{~cm}$ below the surface). The As concentrations in the pore water of the greenhouse experiment often significantly exceeded the Flemish soil sanitation thresholds for groundwater. There were indications that As release is not only affected by the reductive dissolution of Fe/Mn oxides, but also by e.g. a direct reduction of $\mathrm{As}(\mathrm{V})$ to $\mathrm{As}(\mathrm{III})$. Below the water table, sulfide precipitation seems to lower As mobility when reducing conditions have been sufficiently established. Above the water table, sulfates and bicarbonates induce As release from the solid soil phase to the pore water.
\end{abstract}

\section{Introduction}

The Scheldt river sources in the north of France, and continues its flow in Belgium through the Walloon and the Flemish Region towards the North Sea outlet in the Netherlands. Its river catchment covers a surface of $20331 \mathrm{~km}^{2}$ in one of the most populated and industrialized areas of Europe. The downstream Scheldt basin is a typical coastal estuary characterized by a small river discharge, but subjected to a large tidal influence with an amplitude of $4.5 \mathrm{~m}$ at the mouth. It is a unique estuary in Europe as the salinity intrusion extends more than $110 \mathrm{~km}$ upstream. The variations in tidal level can still be observed at Ghent, $150 \mathrm{~km}$ from the river mouth. The Scheldt river is, however, also highly polluted, as it receives industrial and domestic wastewaters. There is a high degree of organic and inorganic contamination. ${ }^{1}$ In particular, vegetated intertidal marshes can be considered as efficient scavengers for polluted particles. ${ }^{2,3}$ Such estuarine floodplains are often polluted by trace elements and various factors can affect their mobility and availability. ${ }^{4}$

Previous papers focusing on the fate of pollutants in intertidal marshes along the river Scheldt studied the factors affecting Cd, $\mathrm{Cr}, \mathrm{Cu}, \mathrm{Ni}$, and $\mathrm{Zn}$ accumulation $^{5,6}$ as well as the factors affecting the mobility and availability of these metals in these

${ }^{a}$ Laboratory of Analytical Chemistry and Applied Ecochemistry Ghent University, Faculty of Bioscience Engineering, Coupure Links 653, B-9000 Ghent, Belgium. E-mail: Gijs.DuLaing@UGent.be

${ }^{b}$ Interdisciplinary Graduate School of Medicine and Engineering, University of Yamanashi, Takeda, 4-3-11Kofu, Yamanashi, 400-8511, Japan

'Soil- and Groundwater-Management, Institute for Soil Engineering, Water- and Waste-Management, Department D, University of Wuppertal, Pauluskirchstraße 7, 42285 Wuppertal, Germany environments. ${ }^{7-13}$ However, there are some indications that the Scheldt estuary is also polluted by arsenic at selected locations. ${ }^{14}$ As arsenic pollution has been noted in several other river catchments worldwide, e.g. ref. 15-17, and arsenic shows a wide range of toxic effects, e.g., dermal, respiratory, cardiovascular, reproductive, mutagenic and carcinogenic effects, ${ }^{18}$ it also deserves considerable attention.

Lots of studies have previously focussed on factors affecting As accumulation and its release from soils. These studies revealed that As is released under reducing conditions in flooded soils, ${ }^{19}$ although the factors affecting As accumulation and mobility in soils under different hydrological conditions are still being discussed in the international literature, e.g. ref. 20 and 21. This discussion is probably partly due to the fact that different authors studied different types of wetland soils and hydrological conditions, and studied As release at different sampling times and depths within the soil, which was done in different types of experimental setups. Therefore, our objectives were to study the factors affecting As accumulation and mobility at different sampling depths in a range of intertidal marsh soils, subjected to different water table levels within one experimental setup. Field sampling was conducted to study factors affecting As accumulation in the upper $1 \mathrm{~m}$ layer of eleven marsh soils of the Scheldt estuary, whereas a greenhouse experiment was set up to study As mobility as affected by water table level and sampling depth within four of these soils. The greenhouse experiment lasted for 298 days, which aimed at reaching steady-state conditions and allowing microbial communities to be established. Arsenic was measured in pore water samples collected above and below the water table, next to other parameters, such as total inorganic and organic carbon, sulfates, Fe and Mn concentrations. Correlation-based data processing was chosen as basis for the discussion. 


\section{Materials and methods}

\subsection{Experimental setup}

2.1.1. Field sampling. The study was carried out in the Belgian part of the Scheldt estuary between Berlare and Doel, which is subject to tidal influences. Eleven study sites were selected (Fig. 1). They all consist of tidal marshes, vegetated especially by common reed, Phragmites australis (Cav.) Trin. ex Steud. They are inundated at high tides, some only at springtides. Moreover, their flood frequency and duration are subject to temporal changes, e.g. due to seasonal variations in the river water discharges. ${ }^{22}$

The marshes "Konkelschoor" in Berlare, "Kramp" in Kastel, "Bornem" in Bornem and "Kijkverdriet" in Steendorp are situated in the freshwater part of the estuary, at 131.39, 114.45, 98.11 and $94.39 \mathrm{~km}$ from the river mouth, respectively. A series of marshes is situated near Rupelmonde, Bazel and Kruibeke, which will be referred to as "Rupelmonde", "Bazel" and "Kruibeke". These are situated at 91.71, 88.94 and $86.35 \mathrm{~km}$ from the river mouth, respectively. They have recently been disturbed to a large extent by the construction of the largest controlled flooding area in Flanders, which should protect the inhabited areas near the river Scheldt from flooding. The "Galgenweel" marsh in Burcht is located at $79.45 \mathrm{~km}$ from the mouth. When moving downstream, it is the first marsh which is significantly affected by brackish water. The marsh near "SintAnnastrand" (75.99 km from the mouth) is rather small and very sandy, as it is situated near an artificially created beach in the city of Antwerp. The "Lillo" marsh is located in the middle of the harbor of Antwerp, at $61.82 \mathrm{~km}$ from the river mouth. The "Doel" marsh is the sampling site which is situated closest to the river mouth $(55.66 \mathrm{~km})$ and near the Dutch-Belgian border. Together with the "Saeftinghe" marsh, just across the border in The Netherlands, it forms the largest brackish-water marsh in Europe.

Within each of these marshes, three soil cores $(3 \mathrm{~cm}$ diameter were sampled in a triangle using an auger. They were sampled at

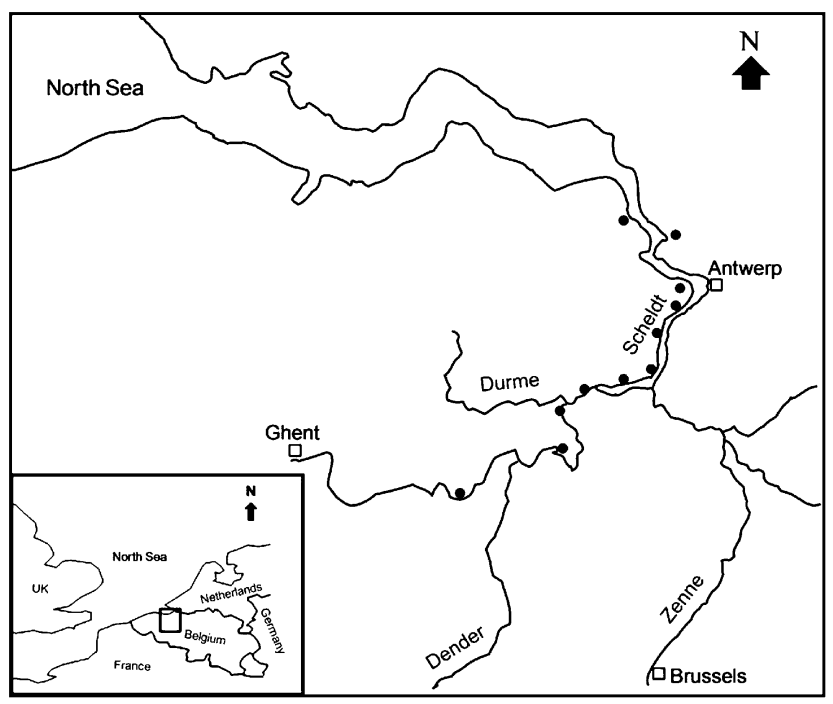

Fig. 1 Study area and sampling locations (reproduced from ref. 14 with permission from Elsevier). approximately 3 metres from each other. Within the "Doel" marsh, 3 of these sampling sites were selected at a distance of approximately $10 \mathrm{~m}$ from each other, aiming at the assessment of within-marsh variability. These will be referred to as Doel A, Doel B and Doel C. The marsh soils were sampled at low tide. Four depths were sampled: 0-20 cm, 20-40 cm, 40-70 cm and $70-100 \mathrm{~cm}$ below the soil surface. The samples were transported to the laboratory in plastic bags. Subsamples were air-dried during three weeks and subsequently ground in a hammer-cross beater mill (Gladiator BO 3567). Another part was not dried and ground for the determination of acid volatile sulfide contents, as drying can induce the oxidation of the sulfides. ${ }^{6,12}$

2.1.2. Greenhouse experiment. A part of the upper $40 \mathrm{~cm}$ intertidal soil layer was excavated at Bornem, Kijkverdriet, Konkelschoor and Lillo. The soils were thoroughly homogenised. Fifteen PVC tubes with a diameter of $16 \mathrm{~cm}$ and a length of $1 \mathrm{~m}$ were closed at the bottom. In accordance to Meers et al.,$^{23}$ Rhizon soil moisture samplers (type MOM, Rhizosphere Research Products, Wageningen, The Netherlands, pore size < $0.2 \mu \mathrm{m}$ ) were selected for extraction of the soil solution, as these samplers were found to be sufficiently sensitive with no significant retention/adsorption effects on trace metals when used for water extraction from soil matrices. The Rhizon soil moisture samplers, equipped with extension tubes were installed vertically inside the tubes at fixed distances from the bottoms of the PVC tubes. The effect of soil heterogeneity was diluted by duplicating the sampling procedure, i.e. two samplers were installed at each sampling depth in each tube, at least $15 \mathrm{~cm}$ away from each other. Three tubes were filled up with each type of soil up to 95 $\mathrm{cm}$ of the bottom, meanwhile taping the Rhizon samplers to the walls of the tubes so that the $10 \mathrm{~cm}$ long filter tubes of the samplers were situated at fixed distance intervals of 5-15, 25-35, 55-65 and 85-95 cm below the soil surface. These sampling intervals will be referred to as 10,30,60 and $90 \mathrm{~cm}$ below the soil surface. Before filling the tubes with the soils, perforated PVC tubes with a diameter of $32 \mathrm{~mm}$ were installed in the middle of the tubes. These wells allowed the measurement and control of the level of the water table. They were covered with a stopper after the installation to avoid penetration of significant oxygen amounts into the soils. The recipients were stored in a greenhouse at a temperature controlled between 15 and $25^{\circ} \mathrm{C}$ and a light regime of 16 hours light per day.

Each soil was subjected to three different levels of the ground water table. To achieve this, deionised water was added to the soil until the water table was situated just above the soil surface (i.e. completely waterlogged) (referred to as WL-0), and 40 (WL40) and $80 \mathrm{~cm}$ (WL-80) below the surface. Under natural conditions, the highest water table levels can generally be observed at the younger marshes, whereas a lower mean water table level characterises the older marshes, which are already banked up higher. The level of the water table was assessed by measuring the water height in the wells twice a week. It was adjusted if necessary by addition of deionised water to the soil. Deionised water was used to eliminate possible effects of ions contained in this water. Consequently, ions detected in the pore water were released from the soils themselves. It should, however, be mentioned that natural groundwater and surface water contain ions which might additionally affect As release 
from the soil under more natural conditions. Moreover, the soil was homogenised to eliminate natural variations in properties of the solid soil phase (e.g. total As contents, organic matter and texture) which are also expected to affect As release and might interfere with effects of sampling depth and water table level. Consequently, the soil was disturbed in the beginning of the experiment. Therefore, the experiment lasted for 298 days, aimed at reaching steady-state conditions and allowing microbial communities to establish again.

The first sampling of pore water took place 41 days after the beginning of the experiment to allow the soils to settle around the samplers. Pore water sampling was repeated after 90, 186, and 298 days by connecting vacuum tubes to the sampler's extension tubes. The samples were taken after removal of the water which was still present in the extension tubes from the previous sampling. Samples collected by the two samplers which were installed at each depth of each treatment were poured together in a recipient.

\subsection{Analyses}

All glassware and containers were washed in a laboratory dishwasher, subsequently soaked overnight in 5\% ultrapure $65 \%$ $\mathrm{HNO}_{3}$ and rinsed with deionised water. Acid volatile sulfide contents (AVS) were determined on fresh soil samples by conversion of sulfide to $\mathrm{H}_{2} \mathrm{~S}$ and absorption in a $\mathrm{Zn}$-acetate solution, followed by a back titration, as described by Tack et $a l .{ }^{24}$ The $\mathrm{pH}$ was measured in a $1 / 5$ soil/distilled water suspension after equilibration during $18 \mathrm{~h}{ }^{25}$ The conductivity was measured in the filtrate of a $1 / 5$ soil/distilled water suspension, shaken for $1 / 2$ h. ${ }^{25}$ The organic matter content was determined by measuring the weight loss after incineration of oven-dried samples ( $2 \mathrm{~h}$ at 450 $\left.{ }^{\circ} \mathrm{C}\right)$. The carbonate content was determined by back-titration (with $0.5 \mathrm{M} \mathrm{NaOH}$ ) of an excess of $0.25 \mathrm{M} \mathrm{H}_{2} \mathrm{SO}_{4}$ added to $1 \mathrm{~g}$ of soil. ${ }^{26}$ Texture was determined at the Research Institute for Nature and Forest (INBO, Belgium) using laser diffraction (Coulter LS200, Miami, FL, USA) after removing organic matter and carbonates by adding hydrogen peroxide and an acetate buffer solution, respectively. The mass fraction of organic matter, carbonate, clay, silt and sand is reported as percentage $(\%)$.

Arsenic was analysed in the soil samples using Hydride Generation Atomic Absorption Spectrometry (AAS, Varian, Palo Alto, CA, USA). Extraction of the arsenic from the soils was obtained by digesting them in a mixture of concentrated acids. Five $\mathrm{ml}$ of concentrated $\mathrm{H}_{2} \mathrm{SO}_{4}$ and $2 \mathrm{ml}$ of concentrated $\mathrm{HNO}_{3}$ were added to $0.50 \mathrm{~g}$ of the soil. This mixture was heated for about 30 minutes on a hot plate $\left(220^{\circ} \mathrm{C}\right)$. The samples were allowed to cool down and $2 \mathrm{ml}$ of $\mathrm{H}_{2} \mathrm{O}_{2}$ were added. When the most intensive reactions were completed, the samples were again heated for about one hour. After cooling the samples again, $2 \mathrm{~mL}$ of $\mathrm{HNO}_{3}$ and $2 \mathrm{~mL}$ of $\mathrm{H}_{2} \mathrm{O}_{2}$ were added and heated again. This process was repeated several times until the colour of the solution turned to white. After cooling, $8 \mathrm{ml}$ of $\mathrm{HCl}(12.5 \mathrm{M})$ were added and the samples were filtered into $50 \mathrm{~mL}$ volumetric flasks. In each flask, $2 \mathrm{~mL}$ of potassium iodide solution $(12 \% \mathrm{KI}, 1 \%$ ascorbic acid) was added and finally the mixture was diluted up to $50 \mathrm{~mL}$. The samples were heated in a water bath at $90{ }^{\circ} \mathrm{C}$ for 30 minutes, and subsequently arsenic was analysed after cooling by Hydride Generation Atomic Absorption Spectrometry (HGAAS, Varian, Palo Alto, CA, USA). The reliability of this procedure was checked by analysing certified reference sediment of the Scheldt estuary (BCR CRM 277).

To determine the As concentrations in the pore water of the greenhouse experiment, $10 \mathrm{~mL}$ of pore water was transferred to a $25 \mathrm{~mL}$ volumetric flask. In each flask, $4 \mathrm{~mL}$ of $\mathrm{HCl}(12.5 \mathrm{M})$ and $1 \mathrm{~mL}$ potassium iodide solution $(12 \% \mathrm{KI}, 1 \%$ ascorbic acid) were added. Finally, the mixtures were diluted up to $25 \mathrm{~mL}$. The samples were heated in a water bath at $90{ }^{\circ} \mathrm{C}$ for 30 minutes and arsenic was analysed using HG-AAS after cooling.

In the samples taken on days 41, 186 and 298, total organic (TOC) and inorganic (IC) carbon, sulfate, Fe and Mn concentrations were also analysed, whereas $\mathrm{Fe}$ and $\mathrm{Mn}$ concentrations were also determined in the samples of day 90. Results of these analyses were reported by Du Laing et al. ${ }^{27}$

To detect significant effects of sampling depth, water table level, soil origin and possible interactions among these factors on the As concentrations in the pore water, analysis of variance (ANOVA) was conducted using SPSS 15.0. Tukey post-hoc tests were conducted to detect differences between means at the 0.05 significance level.

\section{Results and discussion}

\subsection{Field monitoring}

3.1.1. Soil characteristics. Characteristics for all studied marsh soils are summarised in Table 1 . The $\mathrm{pH}$ was near to neutral and relatively stable. It varied between 7.4 and 8.2 and was slightly lower in the upper layer, probably because of proton release and acid production upon organic matter decomposition which frequently occur in floodplain ecosystems. ${ }^{28}$ Moreover, a net reduction of electron acceptors (such as sulfates) might be expected at higher sampling depths. Protons are trapped upon reduction of these electron acceptors, which increases the $\mathrm{pH}$. Moreover, it should be mentioned that measured $\mathrm{pH}$ differences might also partly be attributed to the operational analysis procedure, as the $\mathrm{pH}$ was measured on dry samples and protons are released upon oxidation of sulfides. ${ }^{6}$ The relatively low $\mathrm{pH}$ fluctuations might be attributed to the high carbonate buffering capacity. Carbonate concentrations (expressed as $\mathrm{CaCO}_{3}$ ) indeed varied between 1.8 and $17.7 \%$. Conductivities decreased with increasing distance to the river mouth, which coincided with previous observations. ${ }^{5,6}$ Average, median and maximum AVS concentrations clearly increased with depth, as previously also observed by Du Laing et al. ${ }^{6}$ At Rupelmonde, AVS concentrations were very low, even at the $70-100 \mathrm{~cm}$ depth $\left(<2-5 \mathrm{mg} \mathrm{kg}^{-1}\right.$ DM). The marsh soils of Rupelmonde were the most sandy of the studied sites (63.9-69.4\% sand) and contained the lowest organic matter amounts $(2.2-4.7 \%)$. These conditions do not favour strongly reducing conditions.

3.1.2. Arsenic concentrations in soil. The As concentrations in the soils (Table 2) varied significantly with sampling depth and location and the interaction between depth and location $(\mathrm{p}<$ 0.001 ). They varied slightly, from 7.3 to $10.2 \mathrm{mg} \mathrm{kg}^{-1} \mathrm{DM}$, between the three sampling points of Doel situated at a short distance $(10 \mathrm{~m})$ from each other. They were lowest in Doel, 
Table 1 Summary statistics of soil characteristics at the different sampling depths: $\mathrm{pH}, \mathrm{EC}, \mathrm{CaCO}_{3}$, chloride, OM, clay, silt, AVS and As content (percentages refer to mass fractions; average: average, stdev: standard deviation, med: median, min: minimum, max: maximum; $n=13$; if replicate samples were analysed, the average of each sampling site was taken into account)

\begin{tabular}{|c|c|c|c|c|c|c|c|c|}
\hline depth & $\mathrm{pH}$ & $\mathrm{EC}\left(\mu \mathrm{S} \mathrm{cm}^{-1}\right)$ & $\mathrm{CaCOB}_{3 \mathrm{~B}}(\%)$ & OM $(\%)$ & Clay (\%) & Silt $(\%)$ & $\operatorname{AVS}\left(\mathrm{mg} \mathrm{kg}^{-1} \mathrm{DM}\right)$ & As $\left(\mathrm{mg} \mathrm{kg}^{-1} \mathrm{DM}\right)$ \\
\hline \multicolumn{9}{|l|}{$0-20 \mathrm{~cm}$} \\
\hline average & 7.6 & 1733 & 9.0 & 14.0 & 40 & 49 & 32 & 19.6 \\
\hline med & 7.6 & 1108 & 7.9 & 14.9 & 41 & 50 & 13 & 15.7 \\
\hline $\min$ & 7.4 & 292 & 2.5 & 4.7 & 23 & 29 & 2 & 3.9 \\
\hline \multirow{2}{*}{\multicolumn{9}{|c|}{$20-40 \mathrm{~cm}$}} \\
\hline & & & & & & & & \\
\hline med & 7.8 & 1263 & 6.7 & 11.1 & 39 & 46 & 33 & 15.1 \\
\hline $\min$ & 7.4 & 209 & 1.8 & 3.0 & 14 & $<2$ & $<2$ & 3.1 \\
\hline $\max$ & 8.2 & 5077 & 12.4 & 22.5 & 58 & 54 & 132 & 119.9 \\
\hline \multicolumn{9}{|l|}{$40-70 \mathrm{~cm}$} \\
\hline average & 7.8 & 1698 & 7.6 & 11.5 & 39 & 42 & 103 & 40.4 \\
\hline stdev & 0.2 & 1180 & 2.7 & 5.7 & 14 & 10 & 110 & 44.5 \\
\hline med & 7.8 & 1346 & 8.2 & 11.4 & 43 & 45 & 65 & 25.6 \\
\hline stdev & 0.2 & 1260 & 3.7 & 4.2 & 13 & 9 & 142 & 39.0 \\
\hline med & 7.9 & 1133 & 9.7 & 10.8 & 45 & 46 & 99 & 37.4 \\
\hline $\min$ & 7.4 & 299 & 2.7 & 2.2 & 12 & 21 & 3 & 2.3 \\
\hline $\max$ & 8.1 & 3903 & 15.0 & 15.2 & 55 & 53 & 533 & 134.3 \\
\hline
\end{tabular}

Table 2 Arsenic concentrations of the soils at the different sampling sites $\left(\mathrm{mg} \mathrm{kg}^{-1} \mathrm{DM} \text {, mean } \pm \text { standard deviation, } \mathrm{n}=3\right)^{a}$

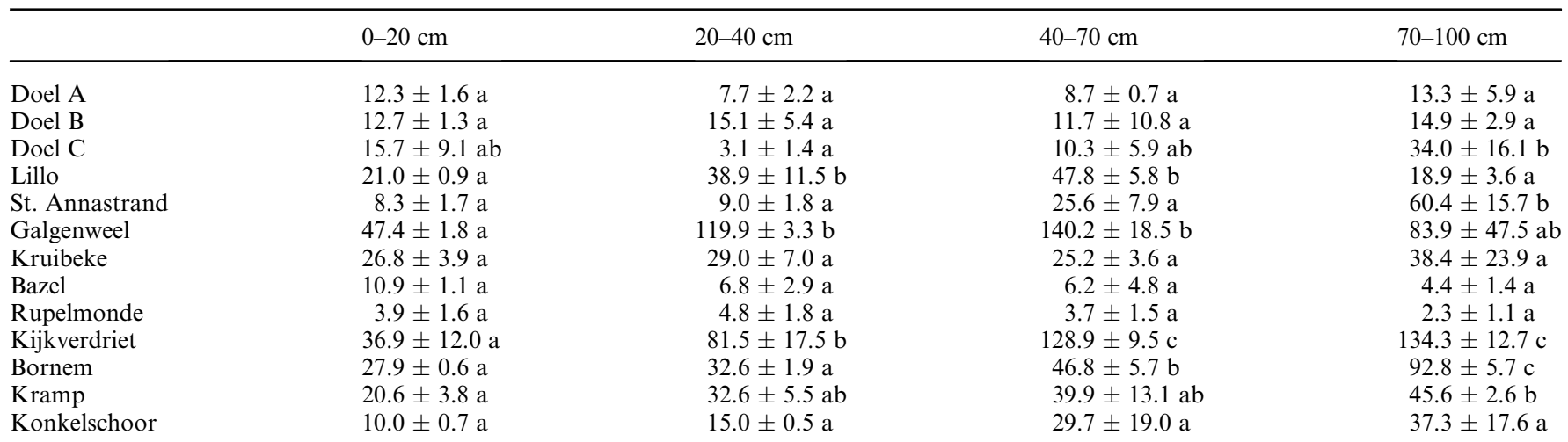

${ }^{a}$ Different letters denote significant differences between soil layers at each sampling site, according to the Tukey post hoc test at the 0.05 significance level.

Rupelmonde and Bazel, where the soils contained relatively little clay (11.5-40.9\%) and organic matter (2.2-13.6\%). They were highest in Kijkverdriet and Galgenweel, and also very high in Bornem, coinciding with the sites at which very high clay (46.6$58.9 \%$ ) and organic matter (13.6-25.4\%) contents were observed. Thus, clay and organic matter seem to affect the As accumulation in the marsh soils. Indeed, average As contents are significantly correlated with average organic matter $(\mathrm{r}=0.610, \mathrm{p}<$ $0.001)$ and clay contents $(r=0.598, p<0.001)$. Moreover, Galgenweel is the first sampling location which is situated in the brackish water part of the estuary, when moving downstream. Polluted particles are expected to settle there as a result of flocculation of suspended solids upon increasing salinity. ${ }^{2,29}$ Significant, positive correlations were observed for the sampling points at $0-20 \mathrm{~cm}$ below the soil surface between the average organic matter contents and average As contents (mentioned as " $10 \mathrm{~cm}$ " in Fig. 2; $\mathrm{r}=0.847, \mathrm{p}<0.001$ ), which has previously also been observed in the Scheldt estuary for $\mathrm{Cd}, \mathrm{Cr}, \mathrm{Cu}, \mathrm{Ni}, \mathrm{Pb}$ and $\mathrm{Zn},{ }^{5}$ and for As also elsewhere. ${ }^{30-32}$ However, other factors seem to affect As accumulation at greater depths, as correlations decrease when moving to the deeper soil layers and higher organic matter contents. The higher the organic matter or clay content, the more observed As concentrations deviated from the concentrations which were predicted based on the relationships between As and organic matter at the $10 \mathrm{~cm}$ sampling point (Fig. 2). In general, the highest deviations were found at sampling points at which the soils also contained significant AVS amounts, and vice-versa. This suggests an important influence of sulfide precipitation in 


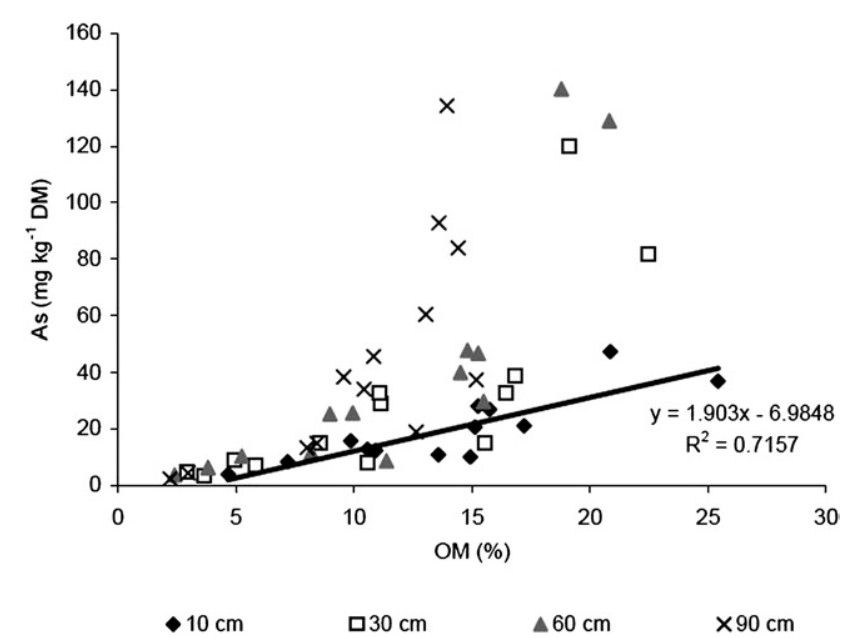

Fig. 2 Relationship between As contents and organic matter contents in the soils as a function of sampling depth. The trend line represents the linear regression between As contents and organic matter contents at the $10 \mathrm{~cm}$ sampling point.

As accumulation at greater sampling depths, as previously observed for $\mathrm{Cd}, \mathrm{Cu}, \mathrm{Pb}$ and $\mathrm{Zn}$ in intertidal sediments of the Scheldt estuary ${ }^{6}$ and for As in other environments. ${ }^{33}$ However, it cannot be excluded that a historically higher pollution grade affected the As contents locally by covering of strongly polluted marsh soils with younger, less polluted sediments.

\subsection{Greenhouse experiment}

3.2.1. Arsenic concentrations in pore water. The As concentrations in the pore water of the greenhouse experiment (Fig. 3) often significantly exceeded the Flemish soil sanitation threshold for groundwater, which is set at $12 \mu \mathrm{g} \mathrm{L}^{-1}{ }^{34}$ They reach up to $1213 \mu \mathrm{g} \mathrm{L}^{-1}$, i.e. about 121 times the WHO drinking water limit of $10 \mu \mathrm{g} \mathrm{L}^{-1}$. Such high concentrations were previously already observed during field monitoring in floodplain soils of other regions, e.g. ref. 17 and 35 . They were significantly affected by soil origin, and water table level, as well as by interactions between both (Table 2). The average As concentration was significantly higher in Bornem $\left(168.0 \mu \mathrm{g} \mathrm{L}^{-1}\right)$ compared to Lillo (78.5 $\left.\mu \mathrm{g} \mathrm{L}^{-1}\right)$, Kijkverdriet $\left(60.5 \mu \mathrm{g} \mathrm{L}^{-1}\right)$ and Konkelschoor (10.6 $\left.\mu \mathrm{g} \mathrm{L}^{-1}\right)$. The high concentration in Bornem should be mainly attributed to the very high As contents in its pore water at sampling day 90 (up to $1213 \mu \mathrm{g} \mathrm{L}^{-1}$ ). Indeed, when this sampling day was removed from the dataset, the average concentration of Bornem evolved towards $74.2 \mu \mathrm{g} \mathrm{L}^{-1}$. The effect of sampling depth was probably also masked by these very high As contents in the pore water of the Bornem soil at sampling day 90. Indeed, when day 90 was removed from the dataset, the effect of sampling depth was also significant $(p=0.002)$, with As concentrations increasing with increasing sampling depth. The average As concentrations as a function of water table level are presented in Fig. 3. They were significantly higher when the water table was kept at the soil surface $\left(145.3 \mu \mathrm{g} \mathrm{L}^{-1}\right)$ compared to when it was kept at $40 \mathrm{~cm}\left(62.6 \mu \mathrm{g} \mathrm{L}^{-1}\right)$ or $80 \mathrm{~cm}\left(30.4 \mu \mathrm{g} \mathrm{L}^{-1}\right)$ below the soil surface. This clearly confirms the role of reducing
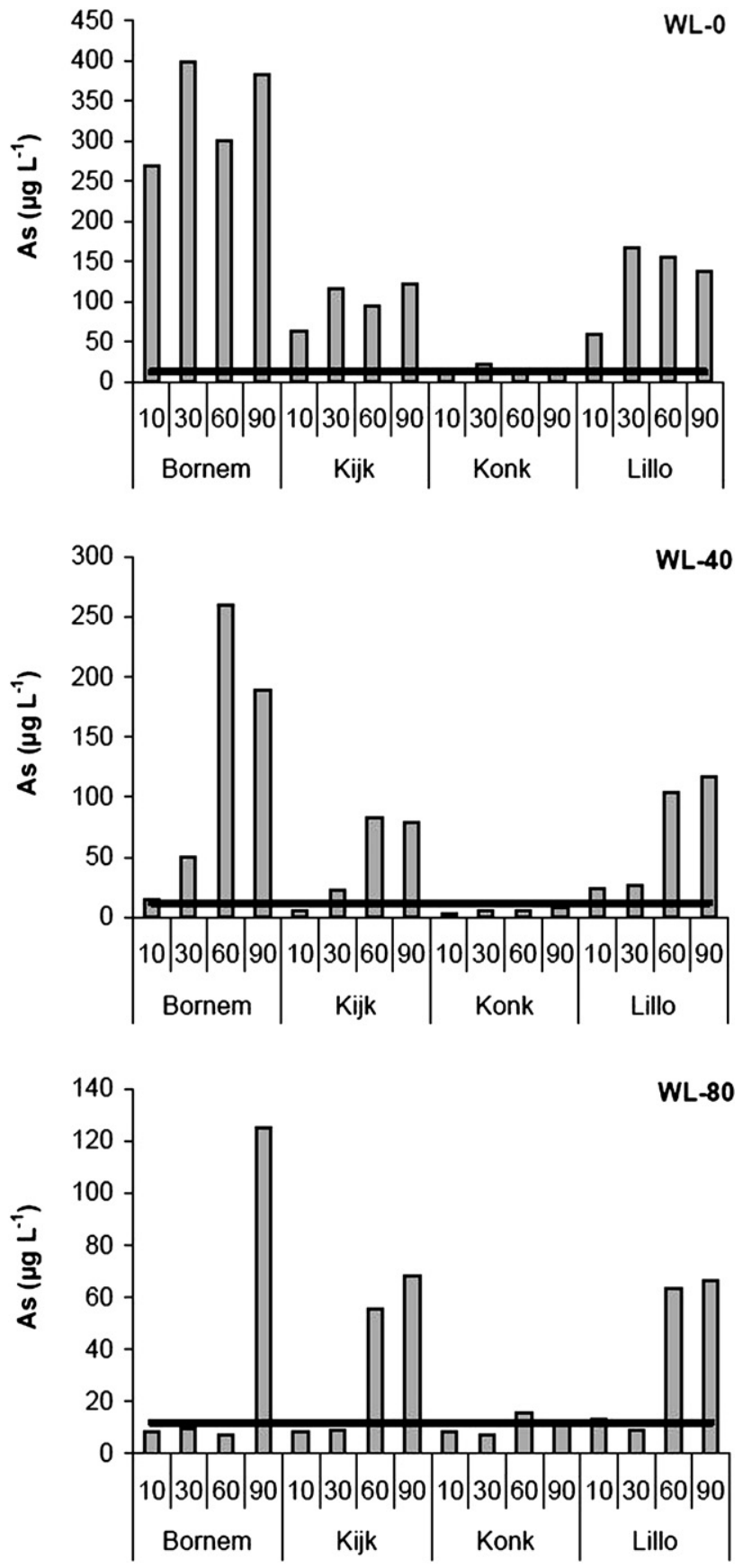

Fig. 3 Average As concentrations at different sampling depths (10, 30, 60 and $90 \mathrm{~cm}$ ) below the surface of 4 floodplain soils (Kijk: Kijkverdriet, Konk: Konkelschoor), upon adjusting the water level to 0 (WL-0), 40 (WL-40) and 80 (WL-80) $\mathrm{cm}$ below the soil surface (please note different scales).

conditions in the mobilisation of As, which has also been observed in other experiments. ${ }^{33,36}$

3.2.2. Relation between As and Fe/Mn. Arsenic sorption in an aerated soil is considered to be largely controlled by $\mathrm{Fe}$ (hydr)oxides and to a lesser extent Mn (hydr)oxides, ${ }^{37}$ which can be proven by conducting selective extractions. ${ }^{35,38}$ As a result, reductive dissolution of these $\mathrm{Fe}$ and $\mathrm{Mn}$ (hydr)oxides upon 
creation of wetland conditions can be accompanied by the release of adsorbed or occluded As. Although there is a wide consensus over the fact that $\mathrm{Fe}$ and $\mathrm{Mn}$ oxides play a role, the mechanism is not always clear. Masscheleyn et al. ${ }^{39}$ found that a small part of the As was already released before the solubilisation of $\mathrm{Fe}$, but that the amount being released rapidly increased with the amount of $\mathrm{Fe}$ in solution. Both $\mathrm{As}(\mathrm{V})$ and $\mathrm{As}$ (III) were found to be released. Zobrist et al. $^{21}$ in turn stated that especially the dissimilatory reduction of adsorbed arsenate to arsenite results in the increased As mobility. The relationship with Fe concentrations in solution was attributed to the fact that the extent of release of arsenite into solution under reducing conditions is governed by its adsorption onto e.g. ferrihydrite. The latter is decomposed during reduction, resulting in the release of $\mathrm{Fe}^{2+}$ into the solution, next to arsenite. According to Pedersen et al. ${ }^{40}$ and Postma et al.,${ }^{35}$ part of the released As is adsorbed on the surface of the remaining Feoxides. In this way, its release may be delayed.
We also monitored the $\mathrm{Fe}$ and $\mathrm{Mn}$ concentrations in the pore water of our experimental setup, as reported by Du Laing et al. ${ }^{27}$ Significant, positive correlations between $\mathrm{As}, \mathrm{Fe}$ and $\mathrm{Mn}$ concentrations in the pore water were indeed observed, although only from day 186 onwards (Table 3 ). This might be due to the fact that the soil was homogenised prior to experimental setup to eliminate natural variations in properties of the solid soil phase (e.g. total As contents, organic matter and texture) which are also expected to affect As release and might interfere with effects of sampling depth and water table level. Consequently, the soil was disturbed in the beginning of the experiment and it probably took some time to establish $\mathrm{Fe} / \mathrm{Mn}$ oxide reducing microbial communities again, as previously reported in other papers. ${ }^{12,23}$ The time needed to establish Fe/Mn oxide reducing microbial communities and reach equilibrium depends on the experimental conditions. Under optimal conditions for the development of $\mathrm{Fe} /$ $\mathrm{Mn}$ oxide reducing micro-organisms, e.g. when soils slurries are

Table 3 Correlation of As with TOC, IC, sulfate, and Fe and Mn concentrations in the pore water for different data subsets (WL = water level; R = Pearson correlation coefficient, $\mathrm{p}=$ significance, $\mathrm{n}=$ number of samples)

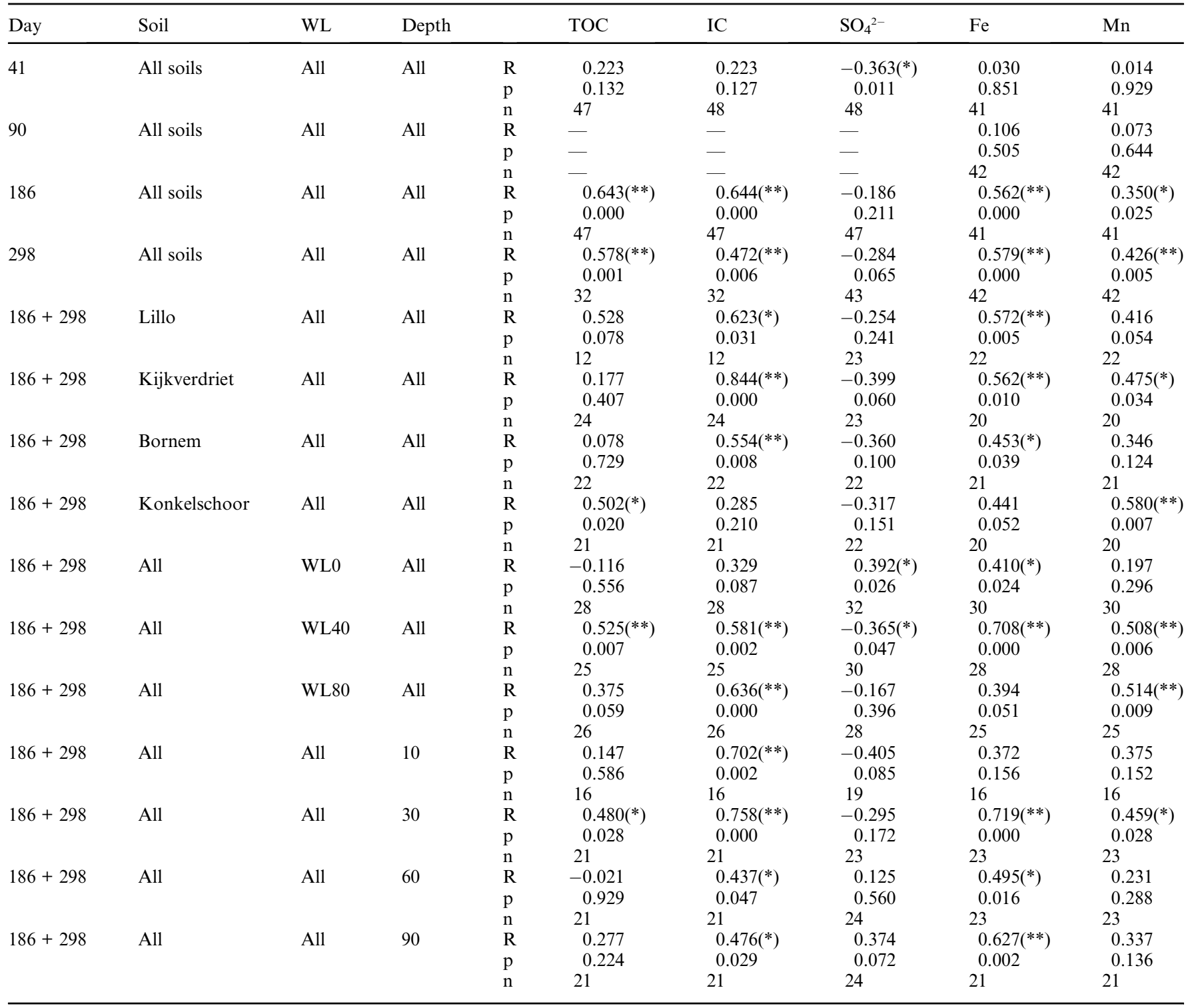




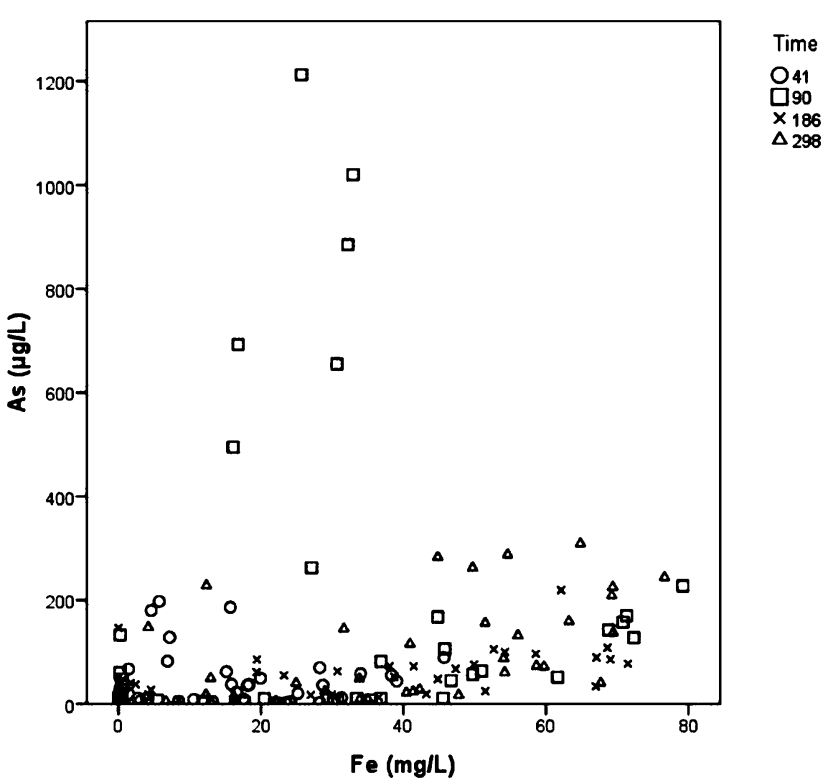

Fig. 4 Relationship between As and Fe concentrations in the pore water as a function of sampling time (days after starting the experiment).

stirred at room temperature and when organic matter is added as food source, equilibrium could be reached within hours or days. However, a few months of inundation can be needed under more natural conditions. ${ }^{\mathbf{8} 12}$ The relationship between $\mathrm{Fe}$ and $\mathrm{As}$ is given in Fig. 4.

3.2.3. Relation between As, organic and inorganic carbon. Next to As, Fe and Mn, we also monitored total organic carbon (TOC) and inorganic carbon (IC) concentrations in the pore water of our experimental setup, as reported by Du Laing et al. ${ }^{27}$ The As concentrations were also significantly, positively

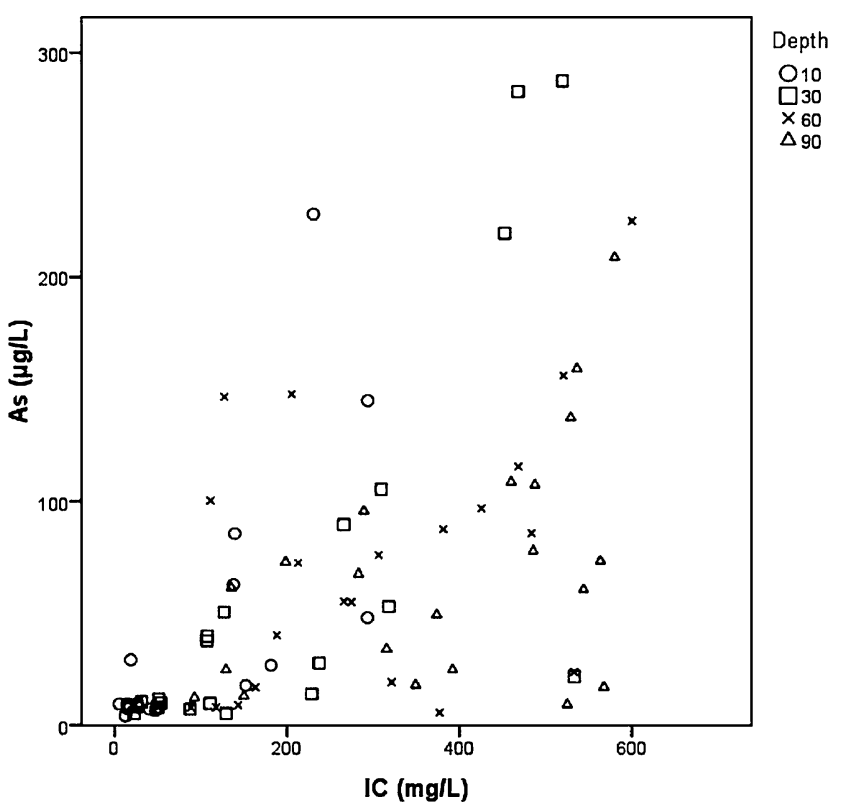

Fig. 5 Relationship between As and inorganic carbon (IC) concentrations in the pore water as a function of sampling depth ( $\mathrm{cm}$ below the soil surface). correlated with total organic carbon concentrations and the total inorganic carbon concentrations (Fig. 5) in the pore water of our setup. The correlation between IC and the arsenic concentration was lowest in Konkelschoor, the soil which had the lowest As concentrations in the pore water. In the same soil, the correlation between As and Mn concentrations was highest and the correlation between $\mathrm{As}$ and $\mathrm{Fe}$ concentrations was lowest. In the upper soil layer (10 $\mathrm{cm}$ below the surface), the presence of IC seems to determine the availability of As, whereas the presence of $\mathrm{Fe}$ and $\mathrm{Mn}$ seems to play a minor role. At $30 \mathrm{~cm}$ below the surface, $\mathrm{Fe}$ and $\mathrm{Mn}$ oxide reduction seems to play an important role, although there is also still a correlation with IC. Below 30 $\mathrm{cm}$ below the surface, the role of IC and Fe/Mn oxide reduction is decreasing, whereas the correlation between As and sulfate becomes positive. When the water table level was kept at $80 \mathrm{~cm}$ below the soil surface, the correlation coefficients decreased in the following order: As-IC $>$ As-Mn $>$ As-Fe $>$ As-TOC, which also illustrates the importance of IC in mobilising As in soil columns above the water table. The relationship with IC might be attributed to the fact that $\mathrm{HCO}_{3}{ }^{-}$and other molecules released during decomposition of organic material to $\mathrm{CO}_{2}$ and subsequent breakdown of carbonates accumulate in soil columns, ${ }^{35,41}$ also to some extent above the water table. These bicarbonates $\left(\mathrm{HCO}_{3}{ }^{-}\right)$probably compete with arsenate for sorption to the solid soil phase in the absence of Fe/Mn oxide reduction. The IC concentrations indeed fluctuated between 5 and $600 \mathrm{mg} \mathrm{L}^{-1}$. ${ }^{27}$ The peak molar IC amount in the pore water thus constitutes a 3000 -fold of the peak molar arsenic amount, so it seems evident that the sorption of arsenic oxyanions to the solid soil fraction is affected by $\mathrm{HCO}_{3}{ }^{-}$. Appelo et al. ${ }^{42}$ and Anawar et al. $^{43}$ indeed suggested displacement by $\mathrm{HCO}_{3}{ }^{-}$to be a main As mobilization mechanism, which has however been disputed by Radu et $a .^{20}$ based on column experiments with synthetic iron oxide-coated sand. The accumulation of IC also indicates the establishment of reducing conditions regardless the presence of $\mathrm{Fe}$ or Mn oxide reduction. These reducing conditions might involve the reduction of $\mathrm{As}(\mathrm{V})$ to $\mathrm{As}(\mathrm{III})$ and subsequent As release which was not a result of $\mathrm{Fe}$ or Mn oxide reduction, as suggested by Zobrist et al. ${ }^{21}$

The fact that the correlation between As and IC is closer compared to the correlation between As and TOC moreover illustrates that the establishment of these reducing conditions is more important for As mobilisation compared to the association of As with soluble organic material. Sisr et al. ${ }^{44}$ indeed also previously observed that the addition of organic manure does not affect the leaching of As from soil in a column experiment. In contrast, Kalbitz and Wennrich ${ }^{45}$ previously also reported a significant, but weak correlation between dissolved organic carbon and As when conducting percolation experiments using small lysimeters with undisturbed topsoil ( $25 \mathrm{~cm}$ height) cores of arsenic-polluted floodplains. Moreover, they observed a low overall As mobility and concluded that there was little risk for groundwater pollution. The whole column was however subjected to a dry period of 6 weeks between simulated rainfall events of only 3 irrigation days per event in a greenhouse without any contact to a water layer underneath in the dry periods. Such flooding regime can occur in a topsoil of a floodplain, but does not allow reducing conditions, as they generally occur in topsoils of wetlands, to be established. ${ }^{12}$ As a result, the topsoils used in 
the percolation experiment of Kalbitz and Wennrich ${ }^{45}$ were much more oxic compared to the soils we used in our experiment, and probably more representative for an periodically flooded floodplain soil than for a wetland soil. Moreover, the soils were less clayey and they had a lower $\mathrm{pH}$, which might have affected its water retention capacity and its binding properties for As and organic matter, respectively.

3.2.4. Relation between As and sulfate. Beside As, Fe, Mn, TOC and IC, sulfate concentrations in the pore water of our experimental setup, as reported by Du Laing et al. ${ }^{27}$ were also monitored. The As concentrations in our greenhouse experiment were negatively correlated with the sulfate concentrations in the pore water $(\mathrm{r}=-0.305, \mathrm{p}<0.001)$ in the upper soil layer (Table 3 ), which was previously already observed in other studies e.g. ref. 46. A positive correlation between As and sulfate was however observed in the deeper soil layers or when the water table is kept at the soil surface. This points towards the presence of sulfate reduction which is expected to result in the precipitation of As with sulfide, limiting the As concentration in the water. ${ }^{47,48}$ Moreover, As may delay sulfate reduction. ${ }^{49}$ Sulfate might also be in competition with arsenite for sorption to the soil solid phase. Saeki ${ }^{50}$ indeed observed that $45 \%$ of the adsorbed As(III) was released from an Andosol by a $0.05 \mathrm{M}$ sodium sulfate extraction procedure, whereas this was less for extraction procedures based on $0.1 \mathrm{M}$ sodium nitrate, $0.033 \mathrm{M}$ sodium dihydrogen phosphate and $1 \mathrm{M}$ hydrochloric acid (30, 15 and $30 \%$, respectively). Ladeira and Ciminelli ${ }^{51}$ found the highest As desorption from an Oxisol to occur when solutions containing sulfate ions were used. Fukuoka et al. ${ }^{52}$ observed the As uptake by pure crystal forms of iron oxyhydroxides to be negatively affected by coexistence of soils, which they also attributed to leaching of sulfate ions from the soils.

3.2.5. Other factors affecting As mobility. Very high As concentrations were observed on day 90 in the Bornem soil, mainly at sampling sites just below the water table (Fig. 3). As the variation of As concentrations around day 90 is much higher compared to the variation of Fe and Mn concentrations (Fig. 4), As is probably not only released due to the reduction of $\mathrm{Fe}$ and $\mathrm{Mn}$ oxides and subsequent release of associated As. The reduction of $\mathrm{As}(\mathrm{V})$ to $\mathrm{As}(\mathrm{III})$, as suggested by Zobrist et al. ${ }^{21}$ probably also plays a significant role when sufficiently low redox potentials are being reached on day 90. This should, however, still be confirmed in future experiments. Moreover, the increasing IC concentrations may also have played a role. The subsequent decrease of As concentrations between days 90 and 186 can be attributed to readsorption of the arsenic on remaining Fe oxides, as suggested by Postma et al., ${ }^{35}$ or more probably to the precipitation of As as sulfides. All sulfates had indeed disappeared below the water table in the Bornem soil from day 186 onwards.

In our study, ions measured in the pore water were released from the soils themselves as deionised water was used to reach the definite water table levels. This was done to eliminate possible effects of ions contained in the water. It should, however, be mentioned that natural groundwater and surface water contain ions which might additionally affect As release from the soil under more natural conditions. In the Scheldt estuary, for example, surface water at sites located closer to the sea contain more sulfates.

\section{Conclusion}

The As concentrations in the studied soils varied significantly with sampling depth and location. Clay and organic matter seem to promote As accumulation in the upper soil layer $(0-20 \mathrm{~cm}$ below the surface), whereas sulfide precipitation plays a significant role in the subsoil (20-100 cm below the surface). The As concentrations in the pore water of the greenhouse experiment often significantly exceeded the Flemish soil sanitation thresholds for groundwater. Arsenic is released more rapidly compared to $\mathrm{Fe}$ and $\mathrm{Mn}$ below the water table in one of the soils, which suggests that the As release is not only affected by the reductive dissolution of Fe/Mn oxides, but also by e.g. a direct reduction of $\mathrm{As}(\mathrm{V})$ to As(III), which should, however, be confirmed in future experiments. After an initial increase, the As concentration often decreases again as a function of time below the water table due to sulfide precipitation, whereas it increases with increasing sulfate concentrations above the water table. The release of As from the soil to the pore water above the water table seems to be affected by the presence of inorganic carbon in the pore water.

\section{Acknowledgements}

We would like to thank the Research Institute for Nature and Forest (INBO, Belgium) for conducting the texture analyses.

\section{References}

1 H. Paucot and R. Wollast, Mar. Chem., 1997, 58, 229-244.

2 I. Temmerman, Water, 1988, 43, 200-204.

3 D. Van Maldegem, H. P. J. Mulder and A. Langerak, Neth. J. Aquat. Ecol., 1993, 27, 247-256.

4 G. Du Laing, J. Rinklebe, B. Vandecasteele, E. Meers and F. M. G. Tack, Sci. Total Environ., 2008, DOI: 10.1016/ j.scitotenv.2008.1007.1025.

5 G. Du Laing, B. Vandecasteele, P. De Grauwe, W. Moors, E. Lesage, E. Meers, F. M. G. Tack and M. G. Verloo, J. Environ. Monit., 2007, 9, 449-455.

6 G. Du Laing, B. De Meyer, E. Meers, E. Lesage, A. M. K. Van de Moortel, F. M. G. Tack and M. G. Verloo, Wetlands, 2008, 28, 735-746.

7 G. Du Laing, N. Bogaert, F. M. G. Tack, M. G. Verloo and F. Hendrickx, Sci. Total Environ., 2002, 289, 71-81.

8 G. Du Laing, A. Bontinck, R. Samson, B. Vandecasteele, D. Vanthuyne, E. Meers, E. Lesage, F. M. G. Tack and M. G. Verloo, Geoderma, 2008, 147, 34-36.

9 G. Du Laing, R. De Vos, B. Vandecasteele, E. Lesage, F. M. G. Tack and M. G. Verloo, Estuar. Coast. Shelf Sci., 2008, 77, 589-602.

10 G. Du Laing, A. M. K. Van de Moortel, W. Moors, P. De Grauwe, E. Meers and F. M. G. Tack, Ecol. Eng., 2008, DOI: 10.1016/ j.ecoleng.2008.1001.1002.

11 G. Du Laing, G. Van Ryckegem, F. M. G. Tack and M. G. Verloo, Chemosphere, 2006, 63, 1815-1823.

12 G. Du Laing, D. R. Vanthuyne, B. Vandecasteele, F. M. G. Tack and M. G. Verloo, Environ. Pollut., 2007, 147, 615-625.

13 G. Du Laing, D. Vanthuyne, F. M. G. Tack and M. G. Verloo, Aquat. Ecosyst. Health Manag., 2007, 10, 33-40.

14 S. K. Chapagain, S. Shrestha, G. Du Laing, M. G. Verloo and F. Kazama, Environ. Int., 2008, DOI: 10.1016/ j.envint.2008.1007.1019.

15 M. Damris, G. A. O'Brien, W. E. Price and B. E. Chenhall, J. Environ. Monit., 2005, 7, 621-630.

16 S. Rattanachongkiat, G. E. Millward and M. E. Foulkes, J. Environ. Monit., 2004, 6, 254-261. 
17 M. Overesch, J. Rinklebe, G. Broll and H. U. Neue, Environ. Pollut., 2007, 145, 800-812.

18 B. K. Mandal and K. T. Suzuki, Talanta, 2002, 58, 201-235.

19 P. H. Masscheleyn, R. D. Delaune and W. H. Patrick, Environ. Sci. Technol., 1991, 25, 1414-1419.

20 T. Radu, J. L. Subacz, J. M. Phillippi and M. O. Barnett, Environ. Sci. Technol., 2005, 39, 7875-7882.

21 J. Zobrist, P. R. Dowdle, J. A. Davis and R. S. Oremland, Environ. Sci. Technol., 2000, 34, 4747-4753.

22 W. Baeyens, B. van Eck, C. Lambert, R. Wollast and L. Goeyens, Hydrobiologia, 1998, 366, 1-14.

23 E. Meers, G. Du Laing, V. G. Unamuno, E. Lesage, F. M. G. Tack and M. G. Verloo, Water, Air, Soil Pollut., 2006, 176, 21-35.

24 F. M. Tack, F. Lapauw and M. G. Verloo, Talanta, 1997, 44, 21852192.

25 E. Van Ranst, M. G. Verloo, A. Demeyer and J. M. Pauwels, Manual for the soil chemistry and fertility laboratory, International Training Centre for Post-Graduate Soil Scientists, University of Ghent, Gent, Belgium, 1999.

26 R. E. Nelson, in Methods of soil analysis, Part 2. Chemical and Microbiological Properties, ed. A. L. Page, American Society of Agronomy, Madison, WI, USA, 2nd edn., 1982, pp. 181-197.

27 G. Du Laing, E. Meers, M. Dewispelaere, B. Vandecasteele, J. Rinklebe, F. M. G. Tack and M. G. Verloo, Sci. Total Environ., 2009, DOI: 10.1016/j.scitotenv.2008.1012.1024.

28 J. Rinklebe, C. Franke and H. U. Neue, Geoderma, 2007, 141, 210223.

29 C. Heip, Water, 1988, 43, 211-213.

30 T. J. Schroder, T. Hiemstra, J. P. M. Vink and S. E. A. T. M. van der Zee, Environ. Sci. Technol., 2005, 39, 7176-7184.

31 I. Varsanyi and L. O. Kovacs, Appl. Geochem., 2006, 21, 949963.

32 C. Yamazaki, H. Ishiga, F. Ahmed, K. Itoh, K. Suyama and H. Yamamoto, Soil Sci. Plant Nutr., 2003, 49, 567-574.

33 J. G. Reynolds, D. V. Naylor and S. E. Fendorf, Soil Sci. Soc. Am. J., 1999, 63, 1149-1156.
34 Vlarebo, Flemish Soil remediation Decree ratified by the Flemisch Government on 22/2/1995, 1996, (translated from Dutch).

35 D. Postma, F. Larsen, N. T. M. Hue, M. T. Duc, P. H. Viet, P. Q. Nhan and S. Jessen, Geochim. Cosmochim. Acta, 2007, 71, 5054-5071.

36 S. L. McGeehan, J. Environ. Sci. Health, Part A, 1996, 31, 2319-2336.

37 W. M. Mok and C. M. Wai, in Arsenic in the environment, ed. J. O. Nriagu, Wiley, New York, 1994, vol. 26, pp. 99-118.

38 P. L. Smedley and D. G. Kinniburgh, Appl. Geochem., 2002, 17, $517-$ 568.

39 P. H. Masscheleyn, R. D. Delaune and W. H. Patrick, J. Environ. Qual., 1991, 20, 522-527.

40 H. D. Pedersen, D. Postma and R. Jakobsen, Geochim. Cosmochim. Acta, 2006, 70, 4116-4129.

41 G. A. van den Berg and J. P. G. Loch, Eur. J. Soil Sci., 2000, 51, $27-$ 33.

42 C. A. J. Appelo, M. J. J. Van der Weiden, C. Tournassat and L. Charlet, Environ. Sci. Technol., 2002, 36, 3096-3103.

43 H. M. Anawar, J. Akai and H. Sakugawa, Chemosphere, 2004, 54, $753-762$.

44 L. Sisr, M. Mihaljevic, V. Ettler, L. Strnad and O. Sebek, Environ. Monit. Assess., 2007, 135, 465-473.

45 K. Kalbitz and R. Wennrich, Sci. Total Environ., 1998, 209, 27-39.

46 J. H. Huang and E. Matzner, Geochim. Cosmochim. Acta, 2006, 70, 2023-2033.

47 M. F. Kirk, T. R. Holm, J. Park, Q. S. Jin, R. A. Sanford, B. W. Fouke and C. M. Bethke, Geology, 2004, 32, 953-956.

48 J. N. Moore, W. H. Ficklin and C. Johns, Environ. Sci. Technol., 1988, 22, 432-437.

49 P. R. Dowdle, A. M. Laverman and R. S. Oremland, Appl. Environ. Microbiol., 1996, 62, 1664-1669.

50 K. Saeki, Soil Sci., 2008, 173, 248-256.

51 A. C. Q. Ladeira and V. S. T. Ciminelli, Water Res., 2004, 38, $2087-$ 2094.

52 H. Fukuoka, N. Shigemoto, H. Inomo and W. Shiraki, J. Chem. Eng. Jpn., 2006, 39, 948-955. 